\title{
DESAIN DAN KONSTRUKSI SISTEM KONTROL POSISI PADA PANEL SURYA DENGAN MENGGUNAKAN SMART PERIPHERAL CONTROLLER(SPC)-STEPPER MOTOR DAN PC-LINK USBER
}

\author{
As'ari ${ }^{1)}$, Michael Kolondam ${ }^{1)}$ \\ ${ }^{1)}$ Program Studi Fisika FMIPA Universitas Sam Ratulangi \\ Jl. Kampus Unsrat Manado, 95115 \\ e-mail: As.ari2222@yahoo.co.id; mkolondam@yahoo.co.id
}

\begin{abstract}
ABSTRAK
Telah didesain dan dirancang sistem pengontrol posisi panel surya terhadap sinar datang cahaya matahari dengan menggunakan SPC-Stepper Motor dan PC-Link USBer, sehingga diperoleh posisi panel surya yang selalu tegak lurus arah sinar datang cahaya matahari. Pengontrolan bidang penampang (panel surya) dilakukan menggunakan motor-stepper yang diprogram dengan bahasa pemrograman assembly. Data yang digunakan sebagai input diperoleh dengan pengukuran sudut datang sinar matahari, sehingga posisi panel surya selalu tegak lurus terhadap sinar datang cahaya matahari. Sistem pengontrol dapat bekerja pada step minimum 1 step $\left(2,8^{\circ}\right)$, dengan interval mulai dari 8 step sampai 50 step (pukul 07:00 sampai pukul 18:00).
\end{abstract}

Kata kunci: Motor stepper, panel surya, system control

\section{CONTROL SYSTEM DESIGN AND CONSTRUCTIONS OF SOLAR PANEL BY USING SMART PERIPHERAL CONTROLLER (SPC)-STEPPER MOTOR AND PC-LINK USBER}

\begin{abstract}
Solar panel position control system to coming ray directions of solar light have been designed and constructed by using SPC-Stepper Motor and PC-Link USBer, so we had solar panel positions that always been rectangular to coming ray directions of solar light. Cross section area of solar panel controlled by using motor-stepper which programmed with assembly programming. Data used as input found by measuring of coming solar ray angles, so solar panel position always be rectangular to coming rays of solar lights. Contolled system could been done at minimum step of 1 steps $\left(2.8^{0}\right)$, the interval is 8 step to 50 step (at 07:00 to 18:00).
\end{abstract}

Keywords: Stepper motor, solar panel, control system

\section{PENDAHULUAN}

Peningkatan kebutuhan akan energi ini mengakibatkan semakin berkurangnya ketersediaan sumber daya alam yang ada, sehingga manusia dituntut untuk mencari sumber-sumber energi lain yang sedapat mungkin sumber energi tersebut dapat diperbaharui. Seiring perkembangan ilmu, teknologi, dan industri energi surya merupakan modal dasar yang kuat untuk dikembangkan sebagai sumber energi terbarukan demi mencapai ketahanan energi di masa mendatang (Leksono, 2010).

Salah satu energi yang paling diperlukan oleh manusia, khususnya di
Indonesia adalah energi listrik. Penyediaan energi listrik di Indonesia masih tergolong rendah. Data DESDM (Dinas Energi dan Sumber Daya Mineral) baru sekitar 66\% masyarakat Indonesia menikmati energi listrik. Fakta yang terjadi saat ini bahwa Indonesia mengalami keadaan dimana pasokan listrik tidak dapat memenuhi kebutuhan masyarakat sebagai konsumen, energi listrik masih terpusat di kota-kota besar, bahkan di Sulawesi Utara sendiri belakangan ini krisis listrik begitu terasa dengan sering diadakan pemadaman dari PLN (Leksono, 2010).

Beberapa alternatif utama sumber energi listrik yang tersedia saat ini antara 
lain: memanfaatkan energi air yang dapat dimanfaatkan untuk memutar turbin, energi angin yang kekuatannya dapat membangkitkan listrik, dan energi matahari yang dihasilkan dengan penggunaan sel surya yang mengubah sinar matahari menjadi energi listrik melalui efek fotovoltaik.

Sumber energi matahari merupakan salah satu sumber energi yang dapat dikembangkan. Energi matahari telah dimanfaatkan di banyak belahan dunia dan jika dieksploitasi dengan tepat, energi ini berpotensi mampu menyediakan kebutuhan konsumsi energi dunia saat ini dalam waktu yang lebih lama. Matahari dapat digunakan secara langsung untuk memproduksi listrik. Untuk mengkonversi energi matahari menjadi energi listrik memerlukan sel surya yang merupakan bahan semikonduktor dengan menggunakan efek fotovoltaik. Menurut data Green Peace Indonesia sumber energi alternatif ini cukup baik. Berdasarkan proyeksi dari tingkat arus hanya $354 \mathrm{MW}$, pada tahun 2015 kapasitas total pemasangan pembangkit tenaga panas matahari akan melampaui 5000 MW. Pada tahun 2020, tambahan kapasitas akan naik pada tingkat sampai 4500 MW setiap tahunnya dan total pemasangan kapasitas tenaga panas matahari di seluruh dunia dapat mencapai hampir $30.000 \mathrm{MW}$, cukup untuk memberikan daya untuk 30 juta rumah(Anonim, 2010).

Salah satu cara untuk mengoptimalisasi kinerja sel surya adalah dengan mencari posisi-posisi dimana bumi menerima panas yang paling maksimal oleh matahari yaitu dengan mencari posisi dimana sinar datang tegak lurus dengan bidang penampang, dalam hal ini panel surya. Dalam penelitian ini panel surya dikontrol dengan menggunakanSPC-Stepper Motor dan PCLink USBer lewat program komputer. Alat ini diharapkan memberikan dampak yang positif dalam perkembangan ilmu pengetahuan, khususnya sebagai bahan pembelajaran. Pada penelitian ini akan dirancang dan dibangun anemometer serta dilakukan optimasi kerjanya.

\section{TINJAUAN PUSTAKA}

Energi panas matahari merupakan salah satu energi yang potensial untuk dikelola dan dikembangkan lebih lanjut sebagai sumber cadangan energi terutama bagi negara-negara yang terletak di khatulistiwa termasuk Indonesia, dimana matahari bersinar sepanjang tahun. Energi matahari yang tersedia adalah sebesar 81.000 Terrawatt sedangkan yang dimanfaatkan masih sangat sedikit (Handoko, 1994). Sumber energi yang melimpah ini jika dimanfaatkan dengan teknologi yang tepat maka akan dapat membantu memenuhi kebutuhan energi yang semakin meningkat.

Sel surya pada dasarnya adalah suatu elemen aktif yang mengubah cahaya matahari menjadi energi listrik.Pada umumnya satu keping sel surya mempunyai ketebalan $3 \mathrm{~mm}$, tersusun atas kutub positif dan negatif yang terbuat dari irisan bahan semikonduktor. Prinsip kerja suatu sel surya adalah dengan memanfaatkan efek fotovoltaik, yaitu suatu efek yang dapat mengubah secara langsung cahaya matahari menjadi suatu energi listrik (Fonash, 2010).

Secara ringkas, ketika sinar matahari mengenai permukaan sel surya, energi dari foton akan dimanfaatkan untuk membentuk pasangan elektron dan lubang (hole) yang merupakan pembawa muatan dalam semikonduktor. Jika dua kutub tersebut disambungkan melalui elektroda, elektron akan mengalir ke semikonduktor tipe-n dan lubang semikonduktor tipe-p ke beban/peralatan listrik (efek fotovoltaik). Sebuah sel surya dengan pembangkit listrik yang lengkap biasanya telah dibuat dalam bentuk modul (panel surya) dan dilengkapi dengan DC-ACInverter (Wenas, 1992). Panel surya dalam pengoperasiannya supaya efektif biasanya menggunakan sistem kontrol, sehingga energy yang dihasilkan akan lebih besar.

Sistem kontrol adalah proses pengaturan ataupun pengendalian terhadap satu atau beberapa besaran sehingga berada pada suatu harga atau dalam suatu rangkuman harga tertentu. Komponenkomponen yang biasanya digambarkan dalam diagram blok adalah kontroler, elemen kontrol akhir, proses, sensor dan transmitter.

Kontroler menggunakan mikrokontroler yang pada dasamya adalah komputer dalam satu chip, yang di dalamnya terdapat mikroprosesor, memori, jalur Input/Output (I/O) dan perangkat pelengkap lainnya. Kecepatan pengolahan data pada mikrokontroler lebih rendah jika dibandingkan dengan Personal 
Computer $(P C)$ Pada $P C$ kecepatan mikroprosesor yang digunakan saat ini telah mencapai orde $\mathrm{GHz}$, sedangkan kecepatan operasi mikrokontroler pada umumnya berkisar antara 1 sampai $16 \mathrm{MHz}$. Begitu juga kapasitas Random Access Memory $(R A M)$ dan Read Only Memory (ROM) pada $P C$ yang bisa mencapai orde Gbyte, dibandingkan dengan mikrokontroler yang hanya berkisar pada orde byte/Kbyte. Meskipun kecepatan pengolahan data dan kapasitas memori pada mikrokontroler jauh lebih kecil jika dibandingkan dengan komputer personal, namun kemampuan mikrokontroler sudah cukup untuk dapat digunakan pada banyak aplikasi terutama karena ukurannya yang kompak (Adi, 2010).

Pada panel surya ditempatkan sebuah motor yang berfungsi sebagi penggerak untuk merubah posisinya. SPC-Stepper Motor merupakan merupakan pengontrol motorstepper yang menggunakan $I^{2} C$-bus sebagai jalur penyampaian data sehingga dapat lebih menghemat dan mempermudah pengkabelan, selain itu SPC-Stepper Motor dapat digunakan secara paralel.

\section{METODE PENELITIAN}

Alat yang digunakan adalah:

1. Catu Daya (9 V dan $5 \mathrm{~V}$ )

2. SPC-Stepper Motor

3. PC-Link USBer

4. Komputer, dengan spesifikasi :
a. Type : Acer $4736 \mathrm{G}$
b. Processor :Intel ${ }^{\circledR} \quad \mathrm{Core}^{\mathrm{TM}} 2$ Duo Processor T6600. $2.2 \mathrm{GHz}$

c. RAM : DDR3 $3 \mathrm{~GB}$

d. Operating System : Windows ${ }^{\odot} 7$ Ultimate Edition, Service Pack 1. x86 (32 bit)

5. Motor-stepper

6. Busur derajat

7. Kabel :
a. Kabel USB (Universal Serial Bus)
b. Kabel data
c. Kabel merah-hitam
Rangkaian terdiri dari beberapa bagian yang dirangkai seperti pada gambar 1 .

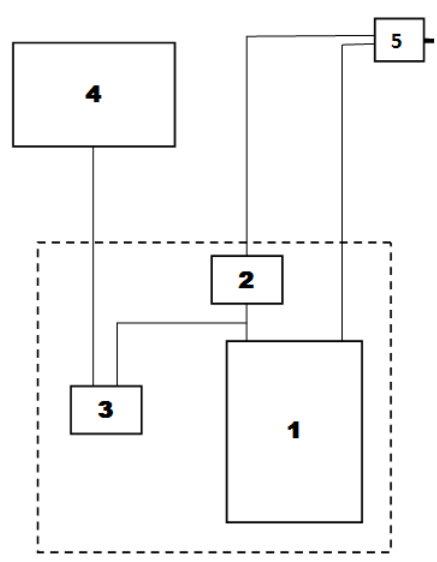

Gambar 1 :Bagan rangkaian alat

Keterangan :

1) Catu Daya; 2) SPC-Stepper Motor; 3) PCLinkUSBer; 4) Komputer/Laptop; 5)Motorstepper

Pengambilan data sudut datang dilakukan dengan meletakkan papan panel surya di atas sebuah batang besi yang sudutnya dapat diubah-ubah, sudut datang matahari $(\theta)$ diukur dengan busur setiap 1 jam, dari pukul 07:00 sampai pukul 18:00. Pengambilan data dilakukan selama 10 hari.

Data ini dipakai sebagai input data dan diujicobakan pada sistem, selanjutnya dianalisis kerja dari sistem kontrol ini.

\section{HASIL DAN PEMBAHASAN}

\section{Desain Sistem Rangkaian}

Blok diagram setiap modul yang digunakan secara keseluruhan dapat dilihat pada Gambar 2. Gambar 2 menunjukkan bahwa terdapat lima modul yang dirangkai. Setiap modul dikoneksikan dengan kabel yang berbeda-beda, yang ditandai dengan angka 1 sampai 5 pada kotak dengan garis putus-putus. 


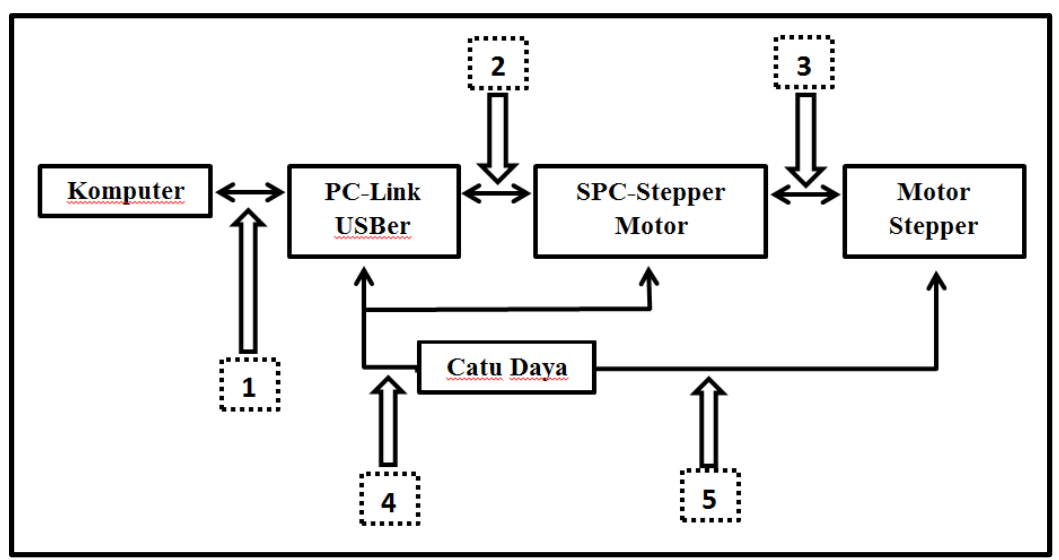

Gambar 2. Blok diagram sistem

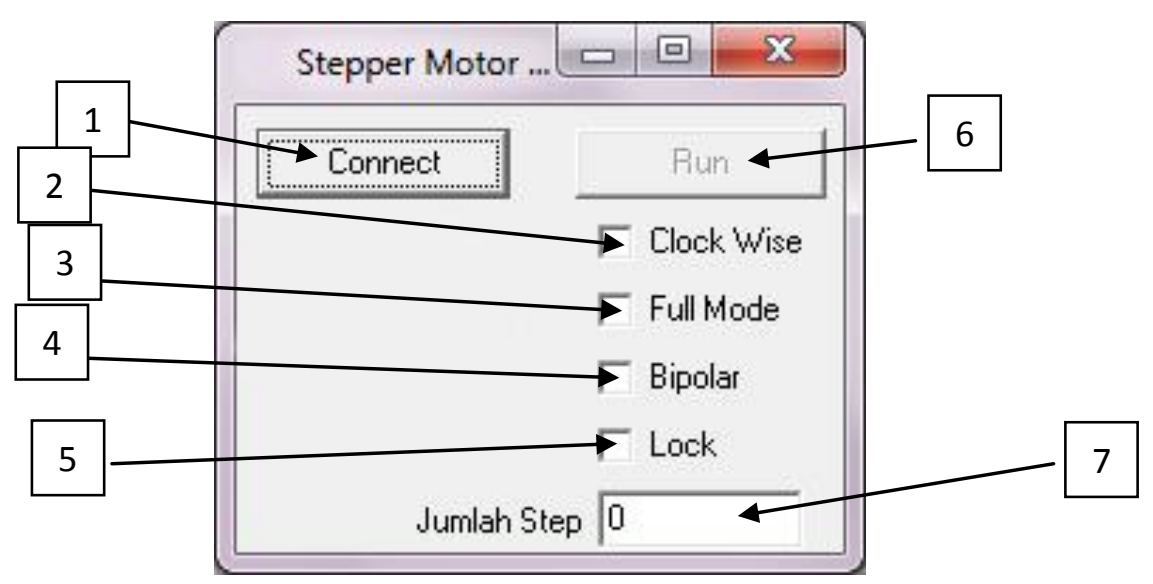

Keterangan:

Gambar 3.Tampilan program yang digunakan

1. Tombol untuk buka/tutup koneksi PC-Link USBer

2. Pilihan arah putar motor-stepper

3. Pilihan mode kerja motor-stepper

4. Pemilihan untuk motor-stepper jenis bipolar dan unipolar

5. Pilihan untuk kondisi Lock

6. Tombol untuk menjalankan program

7. Jumlah Step putaran motor yang diinginkan

1. Koneksi 1, penyambungan ini menggunakan kabel Universal Serial Bus (USB).

2. Koneksi 2, penyambungan antara $S P C$ Stepper Motor dengan PC-Link USBer menggunakan kabel data.

3. Koneksi 3, penyambungan antara motorstepper dengan SPC Stepper-Motor menggunakan kabel data.

4. Koneksi 4 dan 5, penyambungan antara SPC-Stepper Motor dan PC-Link USBer dengan catu daya masing-masing menggunakan kabel yang baik untuk menghantarkan listrik.Yang terpenting pembeda untuk masing-masing kutub. Jangan sampai tertukar karena akan menyebabkan kerusakan alat. Tabel 1 menunjukkan penyambungan catu daya dengan SPC-Stepper Motor dan PC-Link USBer.

Tabel 1.Koneksi catu daya dengan masingmasing komponen

\begin{tabular}{|c|c|c|}
\hline No & $\begin{array}{c}\text { Catu } \\
\text { Daya }\end{array}$ & Komponen \\
\hline 1 & $+5 \mathrm{~V}$ & SPC-Stepper Motor \\
\cline { 3 - 3 } & & PC-Link USBer \\
\hline 2 & $+9 \mathrm{~V}$ & Motor-stepper \\
\hline
\end{tabular}


Untuk mengendalikan motor-stepper maka perlu dilakukan pemrograman lewat komputer. Tampilan program pada layar monitor seperti pada Gambar 3.

\section{Uji Pengontrolan Motor-stepper}

Pengujian pengontrolan motorstepper dilakukan dengan interval 5 step. Step menunjukan besarnya perubahan/pergeseran sudut dalam satu kali perubahan. Pengujian dilakukan untuk mengetahui berapa besar sudut yang dihasilkan setiap stepnya.Hal ini perlu dilakukan karena spesifikasi yang tercantum di alat sering tidak sesuai dengan hasil pada pengukuran. Pengujian dilakukan tiga kali untuk masing-masing step, kemudian diambil nilai rata-ratanya. Derajat per step dihitung dengan cara uji derajat perubahan sudut dengan banyaknya step.

Kecenderungan step terhadap sudut yang dihasilkan diketahui dengan membuat grafik step terhadap sudut rata-rata (gambar 4 ).

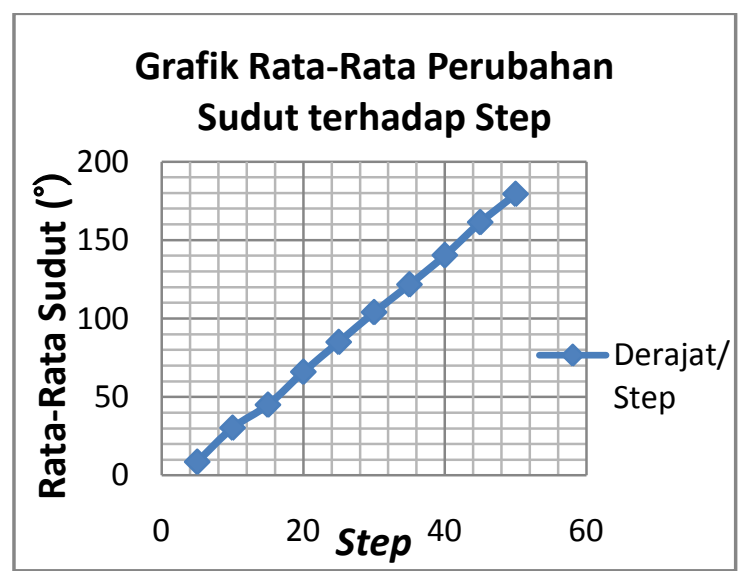

Gambar 4. Grafik uji pengontrolan motorstepper

Gambar 4 menjelaskan bahwa motorstepper yang digunakan memiliki derajat perputaran yang semakin besar apabila step semakin besar.

\section{Data Sudut Datang Sinar Matahari}

Pengambilan data sudut datang sinar matahari yang tegak lurus terhadap bidang penampang (panel surya) yang didapat melalui pengukuran, dilakukan di Badan Meteorologi Klimatologi dan Geofisika (BMKG) Stasiun Klimatologi Kayuwatu selama 10 hari dari tanggal 04 Juli sampai 15 Juli 2011. Pengukuran menggunakan busur serta beberapa alat bantu agar posisi panel surya yang tegak lurus dengan sinar datang dapat ditentukan.

Data pengukuran sinar datang cahaya matahari yang telah diukur, selanjutnya dihitung nilai rata-rata perubahan sudut serta nilai selisih untuk perubahan sudut setiap jamnya. Perubahan posisi matahari terbesar terjadi pada saat pukul 16:00 sampai pada pukul 17:00 yaitu sebesar $21^{\circ}$, sedangkan perubahan posisi matahari yang paling kecil, terjadi pada saat pukul 11:.00 sampai pada pukul 12:00 yaitu sebesar $10,5^{\circ}$. Pada kolom selisih sudut Tabel 2. dapat dilihat bahwa pergerakan matahari pada siang hari lebih kecil dan menjadi semakin besar pada sore hari.

\section{Penentuan Jumlah Step}

Menurut data pengukuran sinar datang cahaya matahari, maka dapat ditentukan berapa jumlah step yang akan digunakan sebagai nilai input ke dalam program. Menentukan jumlah step yang digunakan digunakan Gambar 6. yang menunjukkan grafik derajat/step, dengan nilai axis dan ordinatnya ditukar.

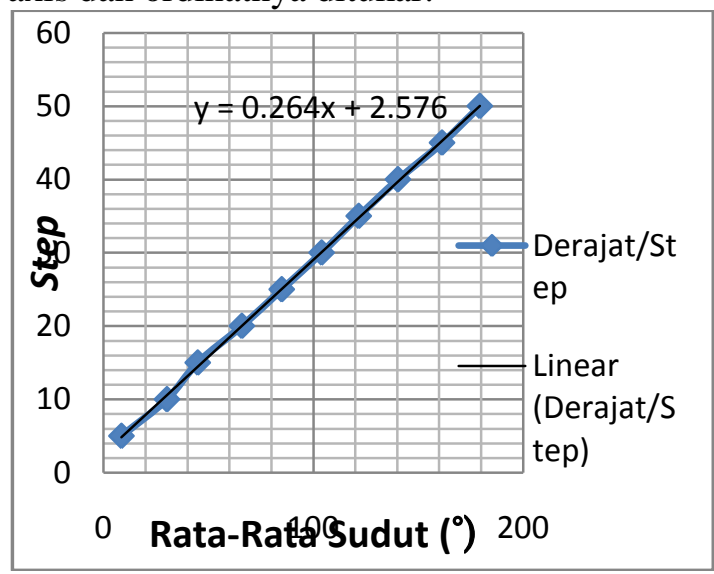

Gambar 5. Grafik penentuan step

Gambar 5. menunjukkan bahwa dengan persamaan (y) dapat ditentukan besarnya step yang akan digunakan pada setiap jam. Hasil jumlah step dibulatkan (Tabel 2) agar supaya dapat di-input pada program, karena motor-stepper hanya membaca nilai yang telah dibulatkan. 
Tabel 2. Jumlah step untuk setiap jam

\begin{tabular}{|c|c|c|}
\hline \hline Waktu & $\begin{array}{c}\text { Rata-rata } \\
\text { Sudut }\end{array}$ & $\begin{array}{c}\text { Jumlah Step } \\
\text { (dibulatkan) }\end{array}$ \\
\hline \hline $07: 00$ & 22 & 8 \\
\hline $08: 00$ & 38,5 & 13 \\
\hline $09: 00$ & 54 & 17 \\
\hline $10: 00$ & 68,5 & 21 \\
\hline $11: 00$ & 79,5 & 24 \\
\hline $12: 00$ & 90 & 26 \\
\hline $13: 00$ & 101 & 29 \\
\hline $14: 00$ & 112,5 & 32 \\
\hline $15: 00$ & 124,5 & 36 \\
\hline $16: 00$ & 140,5 & 40 \\
\hline $17: 00$ & 161,5 & 45 \\
\hline $18: 00$ & 180 & 50 \\
\hline
\end{tabular}

Tabel 2. digunakan untuk mengontrol suatu motor-stepper agar dapat bekerja sesuai dengan pengontrolan yangdiinginkan, yaitu melalui SPC-Stepper Motor dan PC-Link USBer.

\section{Uji Sistem Secara Keseluruhan}

Catu daya dinyalakan untuk menyuplai listrik pada setiap modul. Komputer akan mendeteksi adanya koneksi melalui USB dengan memakai $P C$-Link USBer apabila driver FTD2XXUN telah diinstal, koneksi berhasil apabila ada tampilan "Found NewHardware" pada layar komputer serta ada bunyi notifikasi bahwa komputer sedang dihubungkan lewat USB. Jika tampilan serta bunyi tersebut tidak ada, maka harus dicek lagi pengkoneksian setiap modul yang menandakan adanya kesalahan pengkoneksian. Ditekan tombol "Connect" pada program yang telah dibuat. Selanjutnya, diberikan masukkan data jumlah step yang sebelumya telah ditentukan (Tabel 3.). Saat dimasukkan nilai jumlah step dan mengklik "'Run", maka sinyal-sinyal data digital dikirim lewat laptop yang selanjutnya diolah pada pengontrol SPC-Stepper Motor yang telah memiliki D/A converter untuk mengubahnya menjadi sinyal-sinyal analog yang melewati pin A-D pada motor-stepper, sehingga motor-stepper dapat bergerak sesuai perintah data tersebut. Setelah semuanya diproses, maka motor-stepper dapat bekerja dengan baik.
Tabel 3. Nilai input jumlah step pada program

\begin{tabular}{|c|c|c|c|}
\hline \hline Waktu & $\begin{array}{c}\text { Nilai Input } \\
\text { Jumlah } \\
\text { Step Pada } \\
\text { Program }\end{array}$ & Waktu & $\begin{array}{c}\text { Nilai Input } \\
\text { Jumlah } \\
\text { Step Pada } \\
\text { Program }\end{array}$ \\
\hline \hline $07: 00$ & 8 & $13: 00$ & 3 \\
\hline $08: 00$ & 5 & $14: 00$ & 3 \\
\hline $09: 00$ & 4 & $15: 00$ & 4 \\
\hline $10: 00$ & 3 & $16: 00$ & 4 \\
\hline $11: 00$ & 3 & $17: 00$ & 5 \\
\hline $12: 00$ & 2 & $18: 00$ & 5 \\
\hline
\end{tabular}

Pada Tabel 3. memberikan nilai-nilai step sebagai masukkan/input program, yang memiliki rentang 50 step dengan waktu 11 jam (pukul 07:00 - pukul 18:00). Jumlah step paling kecil yaitu pada pukul 12:00 (2 step) dan paling besar adalah pada pukul 07:00 (8 step), hal ini disebabkan karena program baru dijalankan pada pukul 07:00 dari saat program tersebut pada posisi tidak bekerja, sedangkan nilai step paling besar pada saat program mulai berjalan, yaitu terjadi pada pukul 08:00, 17:00, dan 18:00 (5 step). Gambar 6 menunjukkan grafik kecenderungan nilai jumlah step yang kecil pada siang hari dan besar pada pagi dan sore hari.

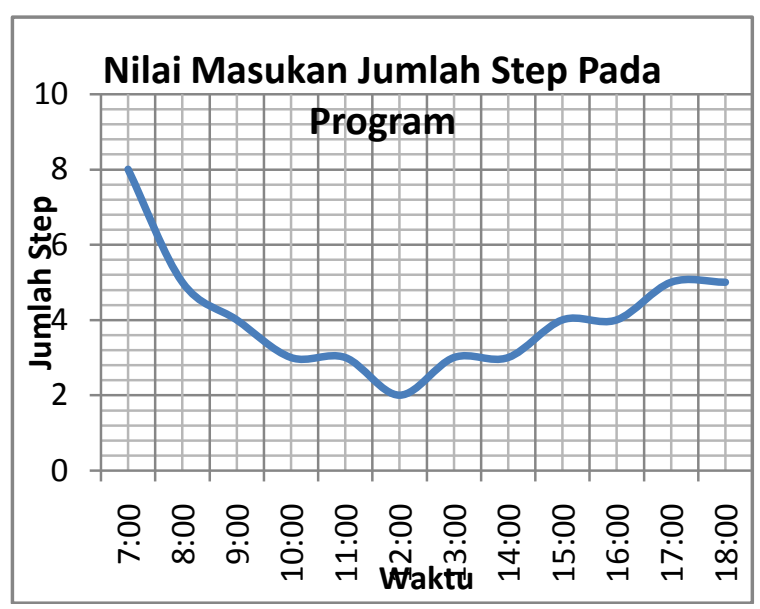

Gambar 6. Grafik input jumlah step pada program

Kecenderungan ini disebabkan karena sudut datang sinar matahari yang sama, pada pagi hari atau sore hari sinar matahari menempuh lintasan di permukaan bumi lebih panjang dibandingkan pada siang hari. 


\section{KESIMPULAN}

1. Telah dibuat sistem pengontrol posisi panel surya terhadap cahaya matahari. Sistem pengontrol yang menggunakan SPC-Stepper Motor dan PC-Link USBer dapat mengatur posisi panel surya dengan besar sudut perubahan yang telah ditentukan.

2. Sistem pengontrol telah dibuat dan dapat bekerja pada step minimum 1 step $\left(2,8^{\circ}\right)$, dengan interval mulai dari 8 step sampai 50 step (pukul07:00 sampai pukul 18:00).

\section{DAFTAR PUSTAKA}

Adi, A.N. 2010. Mekatronika. Penerbit Graha Ilmu. Yogyakarta.
Anonim.2010. http://www.greenpeace.org /seasia/id/. [April 2010]

Fonash, S. 2010. Solar Cell Device Physics. Academic Press. USA.

Handoko. 1994. Klimatologi Dasar : Landasan Pemahaman Fisika Atmosfer dan Unsur-unsur Iklim. Pustaka Jaya. Jakarta.

Leksono, E. 2010. Majalah Energi : Industri Sel Surya Menanti Keberanian Pemerintah. Edisi Desember 2010.

Wenas, W.W. 1992. Teknologi Solar Cell. Jurusan Fisika. Institut Teknologi Bandung [prooceedings] Temu Ilmiah I. 30 Agustus 1992. Persatuan Pelajar Indonesia di Jepang. Kyoto International Community House. Hlm. 236-237 